
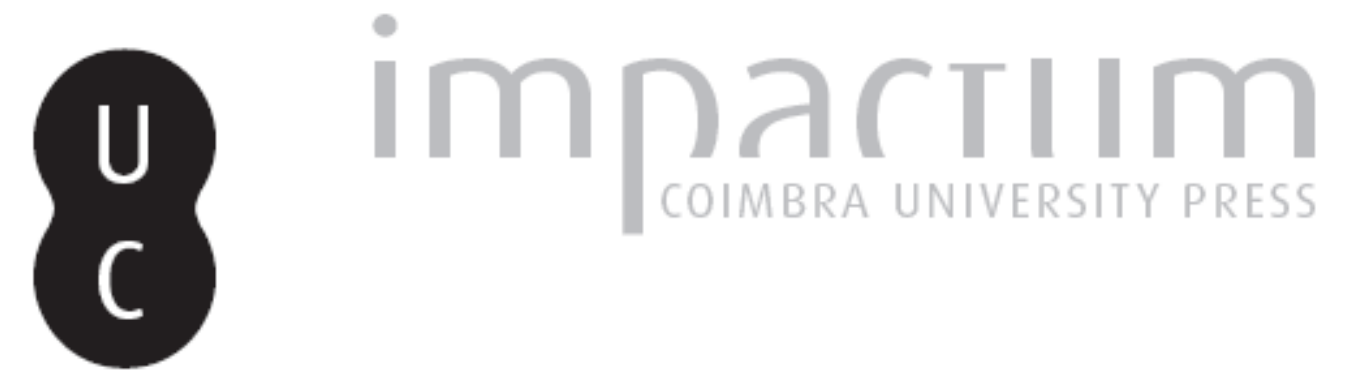

\title{
Parmênides e o caminho da justiça
}

Autor(es): Bentes, Hilda Helena Soares

Publicado por: Universidade Católica de Petrópolis

URL persistente:

URI:http://hdl.handle.net/10316.2/33792

DOI:

DOI:http://dx.doi.org/10.14195/2175-0947_3-1_4

Accessed : $\quad$ 26-Apr-2023 07:20:05

A navegação consulta e descarregamento dos títulos inseridos nas Bibliotecas Digitais UC Digitalis, UC Pombalina e UC Impactum, pressupõem a aceitação plena e sem reservas dos Termos e Condições de Uso destas Bibliotecas Digitais, disponíveis em https://digitalis.uc.pt/pt-pt/termos.

Conforme exposto nos referidos Termos e Condições de Uso, o descarregamento de títulos de acesso restrito requer uma licença válida de autorização devendo o utilizador aceder ao(s) documento(s) a partir de um endereço de IP da instituição detentora da supramencionada licença.

Ao utilizador é apenas permitido o descarregamento para uso pessoal, pelo que o emprego do(s) título(s) descarregado(s) para outro fim, designadamente comercial, carece de autorização do respetivo autor ou editor da obra.

Na medida em que todas as obras da UC Digitalis se encontram protegidas pelo Código do Direito de Autor e Direitos Conexos e demais legislação aplicável, toda a cópia, parcial ou total, deste documento, nos casos em que é legalmente admitida, deverá conter ou fazer-se acompanhar por este aviso.

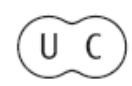



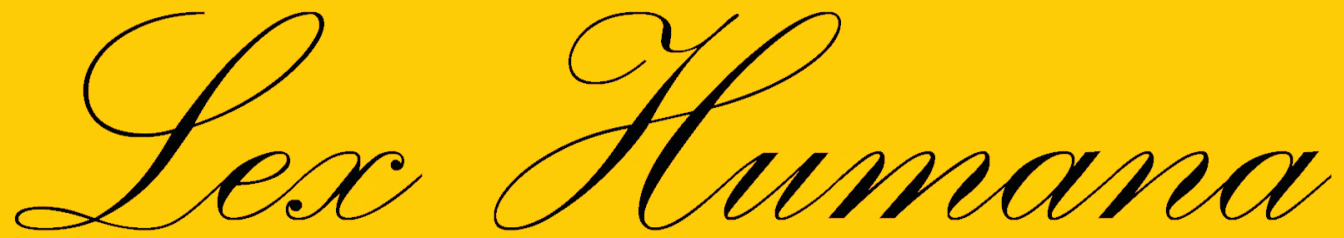

Revista do Programa de Pós-Graduação em Direito da UCP

ISSN(e) 2175-0947

Universidade Católica de Petrópolis Rua Benjamin Constant, 213 - Petrópolis - Centro CEP 25610-130

Tel: (24) 2244-4000 E-mail: lexhumana@ucp.br 


\section{PARMÊNIDES E O CAMINHO DA JUSTIÇA ${ }^{1}$}

Hilda Helena Soares Bentes ${ }^{2}$

Resumo: Propóe-se a analisar o pensamento de Parmênides, indicativo de uma concepçáo de Justiça a meio caminho entre o período pré-socrático e os sistemas filosóficos de Platão e Aristóteles. Inscreve-se Parmênides na fronteira de um pensar mítico e na busca de uma ordenação racional de ideias. $\mathrm{O}$ caminho delineado por Parmênides estabelece vias antitéticas, destacando-se o caminho do conhecimento verdadeiro. Viagem conduzida pela Deusa Justiça, em que se revela o itinerário rumo a um nível de maior abstraçáo, afastandose do plano da dóxa, reino das opinióes contrastantes. Trata-se da viagem do homem sábio em busca da sabedoria, dos fundamentos teóricos que balizam a condição humana e o Direito.

Palavras-chave: Pré-socráticos; Justiça; Conhecimento; Filosofia do Direito.

Abstract: It seeks to analyze Parmenides' thought, expressive of a conception of Justice that can be situated between the presocratic period and the philosophical systems of Plato and Aristotle. Parmenides is classified on the border of a mythical thinking and a search of a rational organization of ideas. The way outlined by Parmenides establishes two antithetical directions, with emphasis on the way of true knowledge. The journey is led by the Goddess of Justice, occasion when the path towards a level of more abstraction is taken, off the dóxa stage, considered the realm of the contrasting opinions. It concerns the journey of the wise man in search of wisdom, of the theoretical bases that founded the human condition and the Law.

Keywords: Presocratics; Justice; Knowledge; Philosophy of Law.

\footnotetext{
${ }^{1}$ Artigo recebido em 13/07/2011 e aprovado para publicação pelo Conselho Editorial em 20/07/2011.

${ }^{2}$ Doutora em Filosofia do Direito pela PUC/SP e Professora Adjunta da Universidade Católica de Petrópolis

- UCP. Currículo Lattes: http://lattes.cnpq.br/7621671933218419. E-mail: hildabentes@uol.com.br.
} 


\section{INTRODUÇÃO}

O tema visa, principalmente, a efetuar uma abordagem sobre a concepção de Justiça esboçada pelo pré-socrático Parmênides. Afigura-se como um caminho necessário para a perfeita compreensão da Justiça o resgate de pensadores que erigiram conceitos matriciais para a Filosofia do Direito, como Anaximandro, Heráclito e Parmênides.

Trata-se, portanto, de recuperar o sentido originário de Justiça e do arcabouço conceitual que os gregos, como os grandes teóricos da Justiça, nos legaram. Parmênides representa um momento culminante do período que antecede aos grandes sistemas filosóficos de Platão e Aristóteles, sendo, portanto, fundamental que a ele retornemos para extrairmos suas preciosas liçóes.

$\mathrm{Na}$ primeira parte uma breve contextualização da biografia de Parmênides é oferecida. Essa etapa é importante para apresentar o momento histórico em que Parmênides viveu e refletiu sobre as vicissitudes da vida humana e as exigências da pólis. Acentuam-se as influências filosóficas que se cruzam no limiar do esplendor dos grandes filósofos gregos, tendo Sócrates como o ponto de referência.

Parte-se, em seguida, para uma análise sobre o poema Sobre a natureza, título comum entre os pré-socráticos e tema recorrente na reflexão levada a cabo por esses pensadores. Poeticamente construído, o poema prenuncia conceitos de enorme ressonância na história do pensamento filosófico ocidental. No que concerne à questáo da Justiça, avultam as figuras míticas de forte simbologia, assim como conceituações que permitem vislumbrar um conceito de Justiça num nível mais abstrato.

E o caminho para a Justiça é delineado por Parmênides, forma pura que busca um sentido incorpóreo. Representa o esforço do homem que persegue a sabedoria localizada num plano de abstração mais pronunciado, distanciando-se do mundo sublunar, móbil, das opiniōes dissonantes. Cuida-se de seguir os passos rumo a uma fonte de saber inusitada e que será desenvolvida com vigor pelos filósofos posteriores.

Nosso caminho é teórico e descritivo. Visa a acompanhar o pensamento instigante de Parmênides através da leitura de seu poema e de seus comentadores. Considerados como 
os grandes teóricos da Justiça, os gregos lançam os alicerces de uma poderosa interrogação e de um problema permanente para a Filosofia do Direito, qual seja, a Justiça.

\section{1- BREVE PERFIL DO PRÉ-SOCRÁTICO PARMÊNIDES}

Parmênides nasceu em Eléia, colônia grega situada no sul da Itália, que viria a constituir-se num centro filosófico de importância capital para o desenvolvimento do pensamento especulativo. A sua biografia é marcada por vários pontos obscuros e controversos, porém sabe-se, de acordo com os relatos doxográficos, que Parmênides teria tido uma enorme projeção devido ao fato de pertencer a uma família de elevada preeminência social e de ter tido uma atuação política significativa ao elaborar uma importante legislaçáo para sua cidade. É, no entanto, no aspecto da cronologia que as maiores incertezas aparecem, provocando divergências insuperáveis. Costuma-se fixar o acme da vida de Parmênides na sexagésima nona Olimpíada (504-500 a.C.), informação derivada de Apolodoro e transmitida por Diôgenes Laêrtios ${ }^{3}$.

É contemporâneo de Heráclito, com quem polemiza por considerar ilusórias e insustentáveis as suas ideias sobre o devir e os opostos. Quanto ao seu nascimento, as discrepâncias aumentam, não obstante a maior parte dos comentadores aceite o testemunho de Platão que relata o encontro de Parmênides, aos sessenta e cinco anos, com o jovem Sócrates em Atenas. Como esse teria sido condenado à morte, em 399 a.C., aos setenta anos, estabelece-se, com alguma precisão, que Parmênides teria nascido em 515 a.C. A data do florescimento fornecida pela doxografia e a do nascimento deduzida de Platáo são

\footnotetext{
${ }^{3}$ John Burnet (1994, p. 142-143) salienta que a informação de Apolodoro, relatada por Diôgenes Laêrtios, leva em consideração a fundaçáo da cidade de Eléia, ocorrida em 450 a.C., época em que se fixa o acme de Xenófanes de Cólofon. Parmênides teria nascido nesta data, da mesma forma como se estabelece o nascimento de Zenão, correspondendo ao florescimento do primeiro, ou seja, por volta de 500 a.C. Vale dizer, Apolodoro costumava fazer combinaçōes entre o acme e o nascimento dos pré-socráticos, o que, para Burnet, não devem ser levadas em consideração. Consultem-se, igualmente, os seguintes autores com relação à biografia de Parmênides: Barnes (1997); Bornheim (1991); Brun (1991); Kirk., Raven, Schofield (1994); Laêrtios (1977).
} 
discordantes, mas o comentário platônico tem prevalecido como historicamente mais relevante. ${ }^{4}$

Várias influências sobre o pensamento de Parmênides são apontadas pela tradição doxográfica, particularmente do pitagórico Ameinias. No entanto, a despeito de algumas ideias místicas presentes na sua doutrina, Parmênides afasta-se do pitagorismo devido ao caráter dualista implícito na teoria dos opostos, que converge, não obstante, para uma "unidade numérica" constituinte das coisas. Presume-se também que teria conhecido Xenófanes de Cólofon. Da crítica ao politeísmo e ao antropomorfismo da religião, Xenófanes postula a existência de um Deus caracterizado pela unicidade, identidade e imobilismo, apreensível pelo pensamento. Esse aspecto da concepção religiosa de Xenófanes é considerado como uma antecipaçáo da teoria parmenideana do Ser, despojada do elemento da divindade absoluta e pensada exclusivamente em termos metafísicos ${ }^{6}$.

Importa sublinhar que Parmênides coloca-se em oposição à filosofia milesiana, em especial ao monismo materialista, ou seja, à tentativa de encontrar uma substância primária criadora do cosmo, e à ênfase no múltiplo como geração e corrupção das coisas. Nega, igualmente, o mobilismo e a doutrina dos contrários de Heráclito, banindo o devir da cogitação filosófica. Todavia, se o conceito de phýsis no pensamento pré-socrático implica uma investigação sobre o Ser em nível metafísico, poder-se-ia afirmar que com Parmênides há a elaboração explícita e rigorosa de uma teoria sobre o Ser de forma radical e definitiva.

\footnotetext{
${ }^{4} \mathrm{O}$ testemunho de Platão encontra-se no diálogo Parmênides (Ou: Sobre as idéias. Gênero lógico), in verbis: "Então, Antifonte disse que Pitodoro lhe contara como, de uma feita, Zenáo e Parmênides vieram as grandes Panatenéias. Parmênides já era de idade avançada, cabeleira inteiramente branca e de presença nobre e veneranda; poderia ter sessenta e cinco anos. [...] Sócrates nesse tempo era muito jovem [...].” In: :

Diálogos de Platáo: Parmênides - Filebo. Trad. Carlos Alberto Nunes. Belém: Universidade Federal do Pará, p. 19-85, 1974, v.VIII. (Coleção Amazônica/ Série Farias Brito), p. 22.

5.PESSANHA, José Américo Motta. Do mito à filosofia. In: Os pré-socráticos: fragmentos, doxografia e comentários. Trad. José Cavalcante de Souza et al. São Paulo: Nova Cultural, 1996. (Os Pensadores), p.20.

${ }^{6}$.Quanto às informaçốes doxográficas, ver particularmente o testemunho de Diôgenes Laêrtios, na obra já mencionada, livro IX, capítulo 3, 21, p.256. Com relação aos comentários acerca das doutrinas pitagórica e a de Xenófanes, consultar Bornheim, 1991, p.30 e 47-48; Kirk., Raven, Schofield (1994, p.172-177; 228-231; 242-246). Vale transcrever o comentário de Aristóteles na Metafísica com relação aos pitagóricos: "[...] Os Pitagóricos, por sua parte, disseram igualmente que existem dois princípios, mas acrescentaram isto, que lhes é peculiar: para êles, o finito e o infinito não são atributos de outras coisas, p. ex. do fogo, da terra ou de algo semelhante, mas o próprio infinito e a unidade constituem a substância das coisas de que são predicados. Eis aí por que o número foi para êles a substância de tôdas as coisas. [...]” In: Metafísica. Trad. Leonel Vallandro. Porto Alegre: Globo, 1969. (Biblioteca dos Séculos), livro I, 987a, 10-20, p.49.
} 
A phýsis (natureza; processo de nascimento e crescimento; natureza de um ser; princípio originário) é o Ser concebido em termos lógicos e abstratos, superando as incertezas da mudança e da multiplicidade ${ }^{7}$.

A importância da doutrina parmenideana pode ser aquilatada no curso da história da filosofia. Parmênides representa um corte significativo em relação às concepções especulativas anteriores e uma alavanca propulsora para o desenvolvimento dos sistemas filosóficos posteriores, desde Platão e Aristóteles até a Idade Média, com reflexos até a Modernidade. É considerado o fundador da Metafísica e da Lógica ${ }^{8}$. Com ele inicia-se um período em que a filosofia adquire autonomia em face dos fatos observáveis da natureza, instaurando, em contrapartida, um rígido esquema dicotômico entre ser e náo-ser, entre essência e aparência, entre verdade e opinião, que repercute há mais de vinte e cinco séculos, ora abstraindo o homem da realidade, ora dilacerando-o, ora apaziguando-o num gigantesco esforço de reconciliação das antinomias propostas pelo filósofo de Eléia9.

\section{2- O POEMA: SOBRE A NATUREZA}

Parmênides é autor de um poema intitulado Sobre a natureza, escrito em versos hexâmetros e composto de duas partes distintas, após um prólogo, de teor marcadamente alegórico: a primeira parte refere-se ao Caminho da Verdade, em que Parmênides expóe com rigor a concepção sobre a verdadeira natureza do real; a segunda denomina-se o Caminho da Opinião, delineado segundo o padrão cosmológico jônio, restando dessa parte

\footnotetext{
7.Cf. especialmente com referência ao afastamento de Parmênides do monismo materialista, Burnet $(O p$. cit., p.150), e Guthrie (1987 p.43-44). Quanto à consideração da phýsis de Parmênides entendida como a procura absoluta do sentido do Ser, ver Gomperz (1949, p.170-172).

8. Cabe assinalar que, conquanto seja atribuído a Parmênides o mérito de ter primeiro formalizado os princípios básicos da Lógica, esta só foi sistematicamente discutida e classificada a partir de Aristóteles, que, superando a dialética platônica, instituiu os instrumentos necessários para a realizaçâo do conhecimento e da elaboraçáo do discurso. Para um aprofundamento da noção de Lógica, suas classificaçóes e desdobramentos, consultar o verbete Lógica, in Mora (1996, p.431-437).

9.Cf. Kirk., Raven, Schofield (Op. cit., p.251); Morente (1980, p.72-79).
} 
poucos fragmentos, o que contribui para manter esses versos remanescentes envoltos numa obscuridade difícil de ser eliminada ${ }^{10}$.

O prólogo do poema transmite ainda a visão de um mundo marcada pela herança mítica, ou seja, a linguagem de Parmênides é ainda poética na medida em que utiliza recursos imagísticos provenientes da história dos "Mestres da Verdade", expressão usada por Marcel Detienne na sua obra Os mestres da verdade na Grécia arcaica ${ }^{11}$, que, através da palavra mágico-religiosa, haviam sido os condutores iluminados da Alétheia (Verdade). Com efeito, o poeta, o adivinho e o rei de justiça são, naquele contexto, os portadores de uma mensagem inspirada, como manifestação da Alétheia, ou seja, da verdade revelada somente àqueles possuidores de uma "memória sacralizada"12, acesso concedido aos privilegiados que têm o dom de penetrar nos mistérios e decifrar o invisível, o absoluto, o inescrutável.

A utilização da simbologia ligada à Alétheia afigura-se não somente adequada para veicular o sentido de uma viagem descobridora e ascensional rumo à Verdade absoluta, como também, simultaneamente, para descortinar toda a carga de ambiguidade que essa palavra encerra, dimensão que Parmênides preserva por ser inerente à condição humana ${ }^{13}$. $\mathrm{Na}$ verdade, o proêmio apresenta a configuração do "homem sábio" ${ }^{14}$ em busca do conhecimento filosófico, modelado ainda em conformidade com as figuras arquetípicas da tradição mítica, e a prefiguração da base estrutural do poema, formada por caminhos antagônicos impregnados por um imaginário alternante de Dia x Noite, de Luz x Trevas, representaçóes metafóricas para expressar a oposição entre Alétheia e dóxa (opinião).

\footnotetext{
${ }^{10}$.Cf. Barnes (1997, p.150); Kirk., Raven, Schofield (1994., p.251); Zeller (1980, p.49-50). Para um melhor entendimento, convém transcrever o significado de verso hexâmetro: "Diz-se de ou verso grego ou latino de seis pés, podendo os quatro primeiros ser dátilos ou espondeus, sendo o quinto dátilo, e o sexto espondeu." In: HOUAISS, Antônio; VILLAR, Mauro de Salles; FRANCO, Francisco Manoel de Mello. Dicionário Houaiss da língua portuguesa. Rio de Janeiro: Objetiva, 2009, p. 1.017.

${ }^{11}$. Cf. 1988, passim.

${ }^{12}$.DETIENNE, Marcel. Os mestres da verdade na Grécia arcaica. Trad. Andréa Daher. Rio de Janeiro: Jorge Zahar, 1988, p.17.

13. Detienne trata explicitamente de Parmênides em diversas partes, podendo-se citar, especificamente, as páginas 14, 69, 70, 71 e 72, da obra citada. Com referência à tradição mítica e à viagem rumo ao saber, vários comentadores abordam o tema; porém, mencionamos aqueles que mais contribuíram para a compreensão do prólogo de Parmênides: Cornford (1981, p.191-195); Gernet (1968, p.241-249); Jaeger (1989, p. 151-152); Marques, (1990, p.43-54).

${ }^{14}$. JAEGER, op. cit., p.152.
} 
Parmênides conta esta viagem rumo à sabedoria alegoricamente no prólogo, que, afortunadamente, foi conservado por Sexto Empírico:

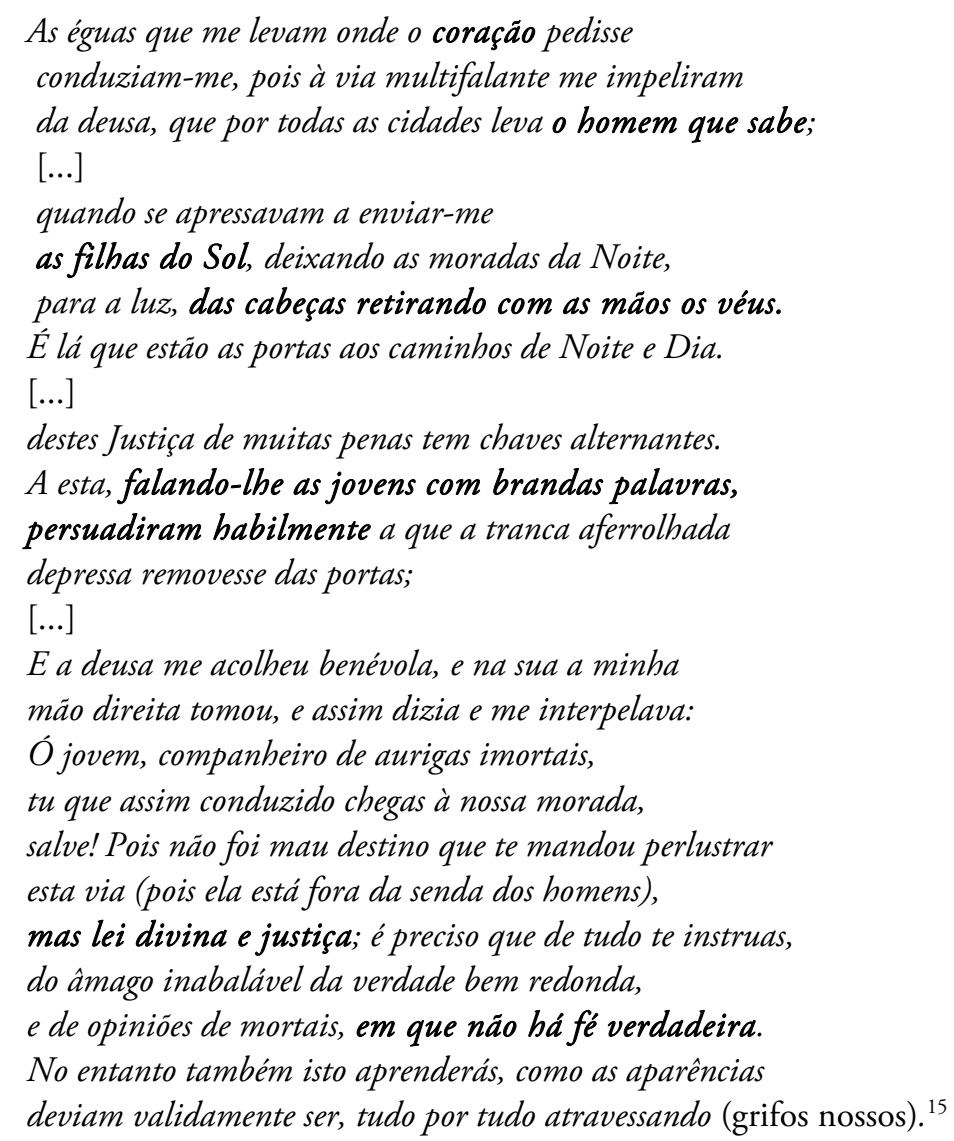

É importante enfatizar que o primeiro verso coloca-nos perante a palavra "coração" (em grego, thymós, geralmente traduzida por coração ou desejo), vital para a compreensão

\footnotetext{
${ }^{15}$.Utilizamos a traduçāo de José Cavalcante de Souza, em PARMÊNIDES DE ELÉIA. Fragmentos: Sobre a natureza. In: Os pré-socráticos: fragmentos, doxografia e comentários. Seleção de textos e supervisão Prof. José Cavalcante de Souza. Trad. José Cavalvante de Souza et al. São Paulo: Nova Cultural, 1996. (Os Pensadores), p.121-122. Importa sublinhar, como fazem Kirk, Raven e Schofield (op. cit., p.254), que o proêmio de Parmênides tem várias ressonâncias com a Teogonia: a origem dos deuses, de Hesíodo, principalmente no que se refere às portas do Dia e da Noite e à revelaçăo transmitida por uma divindade. Cf. em especial os seguintes versos da Teogonia: a origem dos deuses, v. 22-25 e 29-32, p.107: "Elas [as Musas heliconíades] um dia a Hesíodo ensinaram belo canto/ quando pastoreava ovelhas ao pé do Hélicon divino./ Esta palavra primeiro disseram-me as Deusas/ Musas olimpíades, virgens de Zeus porta-égide:/ (...) Assim falaram as virgens do grande Zeus verídicas,/ por cetro deram-me um ramo, a um loureiro viçoso/ colhendo-o admirável, e inspiraram-me um canto/ divino para que eu glorie o futuro e o passado, [...]". In: HESÍODO. Teogonia: a origem dos deuses. 3. ed. rev. Traduçấo e estudo Jaa Torrano. São Paulo: Iluminuras, 1995. (Biblioteca Pólen).
} 
global do poema parmenideano. De fato, o desejo de saber é componente indispensável para impulsionar o homem que busca o conhecimento, ávido por alcançar a compreensão do mundo e do Ser. E nesse percurso, o jovem que se envereda para o caminho da verdade encontra nas divindades uma recepção acolhedora para as suas pretensões, porquanto as filhas do Sol dispóem-se a guiá-lo até a deusa, que o recebe afavelmente, toma-lhe a mão direita e ensina-lhe a verdadeira senda da sabedoria ${ }^{16}$. Essa disposição para o conhecimento abre a possibilidade para o diálogo, permitindo ao jovem ter acesso à palavra sagrada, à memória, em suma, à alétheia. Este processo de des-velamento, sugerido poeticamente pelas filhas do Sol, que "das cabeças retirando com as mãos os véus”, transforma o homem que procura o saber em sophós, palavra que está vinculada ao adjetivo saphés (claro, verdadeiro). O jovem atinge a sua meta: ele contempla a Luz.

Toda a riqueza polissêmica da palavra Alétheia manifesta-se intensamente, pois Peithó, a doce persuasão que a acompanha, faz-se presente no prólogo: as filhas do Sol persuadem Dike (Justiça) a abrir a porta que conduz ao caminho da sabedoria. Associada igualmente à Alétheia, encontra-se Pístis, que corresponde à confiança, à fidelidade. Pístis é um elemento importante no esquema do poema na medida em que dá suporte e credibilidade ao discurso da deusa, revelador de duas vias mutuamente excludentes. Com efeito, a deusa proclama no prólogo que o jovem necessita instruir-se da verdade e da opinião de mortais, "em que não há fé verdadeira". Além disso, a presença de Pístis reforça a idéia de decisão e deliberação do jovem em seguir as palavras divinas e consagrar-se sábio. Esses componentes no poema são indícios relevantes para se desfazer o equívoco de que Parmênides seria um pensador abstrato, alheio a qualquer consideração de natureza emotiva, porquanto "a busca da verdade, para Parmênides, é necessariamente uma questão de fé e de desejo, e apresenta assim toda sua dimensão afetiva, pois é essencialmente um movimento humano." 17

\footnotetext{
${ }^{16}$.Consoante Marcelo Pimenta Marques (Op. cit., p. 44), fica estabelecida uma "relação de reciprocidade" entre o nível humano e o divino, o que impulsiona o desdobramento de todo o poema.

${ }^{17}$.MARQUES, Marcelo Pimenta. O caminho poético de Parmênides. São Paulo: Loyola, 1990. (Coleção Filosofia - 13), p.51. É importante mencionar, como acrescenta o autor citado, a crítica que Nietzsche (1995, p. 57) dirige a Parmênides em contraposição a Heráclito: “[...] também ele é um profeta da verdade, mas parece feito de gelo e náo de fogo, e irradia à sua volta uma luz fria que queima." Ver Detienne (Op. cit.,
} 
Configura-se, no prólogo, uma tessitura complexa em torno da metáfora do caminho, eixo estrutural que se desdobrará na composição de todo o poema. O jovem empreende uma caminhada mítica e filosófica, ultrapassando a obscuridade e vislumbrando a esfera luminosa do conhecimento verdadeiro. Porém, a deusa mostra-lhe não só o caminho da verdade, mas também o caminho do não-ser e o da opiniáo (dóxa), dos quais ele deve instruir-se para ser capaz de chegar a um correto discernimento. O cruzamento dos caminhos no poema é um tema controvertido, mas forçoso é constatar que Parmênides não constrói simplesmente rígidos pares antitéticos e irreconciliáveis; ele insere-se na ambiguidade da palavra Alétheia, trabalha os opostos como constituintes indispensáveis do processo de desvelamento, que necessita do jogo de contrários para poder realizar a síntese almejada. Ademais, em Parmênides entrecruzam-se duas direções existenciais definidas: nele inscrevem-se o sábio, o profeta que adquire o dom da palavra mágica, e, simultaneamente, o legislador, ou seja, o cidadáo da pólis, espectador da emergência da palavra-diálogo, e responsável por ordenar as opiniōes que se confrontam incessantemente ${ }^{18}$.

O tema do caminho remete a uma questão fundamental desenvolvida no poema de Parmênides: o método (méthodos). Com efeito, método é composto de metá e odós (caminho), significando precisamente uma investigação que é efetuada de acordo com um procedimento específico com vistas a alcançar o conhecimento de alguma coisa ${ }^{19}$. Trata-se, portanto, de estabelecer um percurso racional rigoroso, apto a tornar o discurso filosófico inteligível, superador das sendas enganadoras do mundo sensível, onde se contrapóem opiniôes discrepantes. John Burnet considera que o grande mérito de Parmênides reside na invenção de um método de racionar, erigindo as categorias que podem ser pensadas e excluindo as afirmações contraditórias ${ }^{20}$. A apreciação de Werner Jaeger merece ser transcrita por descrever, com pertinência, a correspondência entre a metáfora do caminho e a descoberta do método:

p.70), no que concerne às forças positivas que estão agregadas à palavra alétheia, conferindo-lhe eficácia e realização.

${ }^{18}$.Cf. com relação à temática do caminho e da ambiguidade no poema parmenideano, Marques (Op. cit., p.19-47).

${ }^{19}$.Cf. Chauí (2002, p.505).

${ }^{20}$.Cf. 1994., p.150. 
A descoberta do pensamento puro e da sua necessidade rigorosa surge em Parmênides como a abertura de um novo "caminho", mais, do único caminho praticável para chegar à posse da verdade. A partir deste

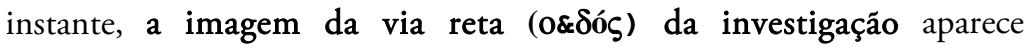
constantemente. E, embora por enquanto não passe de uma imagem, já possui, todavia, uma ressonância terminológica que, especialmente na oposição entre o caminho certo e o errado, se aproxima do sentido do “método". É aqui que tem raízes este conceito científico fundamental. Parmênides é o primeiro pensador que levanta conscientemente o problema do método científico e o primeiro que distingue com clareza os dois caminhos principais que a filosofia posterior há de seguir: a percepção e o pensamento. $O$ que não conhecemos pela via do pensamento é apenas "opiniáo dos homens". Toda a salvação se baseia na substituição do mundo da opinião pelo mundo da verdade. Parmênides considera esta conversão como algo violento e difícil, mas grande e libertador. [...] (grifos nossos). ${ }^{21}$

Nos versos seguintes Parmênides irá demonstrar o seu método de investigação, apontando o Caminho da Verdade como a única possibilidade de aceder ao conhecimento. O método utilizado é a confrontação de duas vias diante das quais o homem tem de decidir que direção tomar sob pena de emaranhar-se numa névoa de contradição: a primeira via é a afirmação de que o Ser é, enquanto que a segunda é a sua negação, indicando que o NãoSer não é. Essas proposiçôes exclusivas visam a superar a ambiguidade mítica contida na palavra Alétheia e a acenar para uma nova formalização com relação ao Ser e à Verdade: claramente identificado, o Ser afasta-se do Não-Ser, que diluído no Nada, nada dele podese conhecer e dizer. O Ser plenamente concebido é a verdadeira constituição das coisas, a phýsis, a partir da qual o homem metafísico que surge dessa ruptura construirá um discurso calcado no que realmente pode ser pensável e exprimível. É a Razão, deificada por Parmênides, que proclama as palavras fundantes de um novo pensar filosófico:

Pois bem, eu te direi, e tu recebe a palavra que ouviste, os únicos caminhos de inquérito que são a pensar: o primeiro, que é e portanto que não é náo ser, de Persuasáo é o caminho (pois à verdade acompanha);

\footnotetext{
${ }^{21}$.Op. cit, p.151. Ver no mesmo sentido a análise de Bruno Snell (1965, p. 341-354.) acerca do caminho como símbolo na cultura grega.
} 


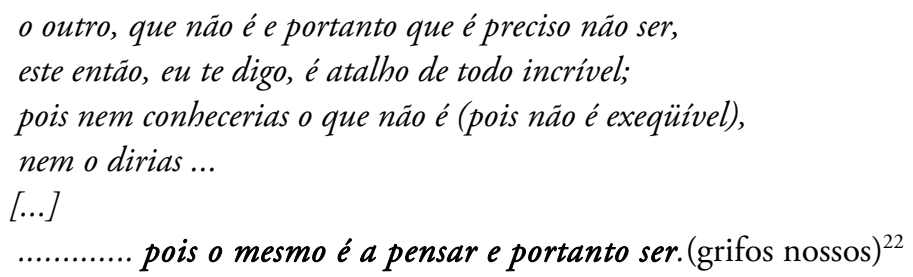

Especialistas observam que o uso do verbo grego einai (ser), desdobrado nos dois enunciados caracterizadores das duas vias de investigação, ou seja, estí (é) e ouk estí (não é), revela o sentido de verdade, de existência, daquilo que é evidente por si mesmo. No poema parmenideano, verifica-se o emprego do uso veritativo do verbo para afirmar o que é ou não real e verdadeiro, centrado na unicidade do Ser, e, igualmente, do uso predicativo para expressar as propriedades inerentes ao Ser único, que é pensado a partir da negação do nada $^{23}$. Parmênides desenvolve ao máximo uma poderosa reflexão metafísica sobre a linguagem, utilizada como recurso para conhecer o real, "em torno de um centro minúsculo, a pequena palavra grega $\varepsilon \sigma \tau \imath$, o verbo 'ser"”24, como analisa Marcel Detienne. O verbo ser transforma-se em postulado transcendental, em Ser universal e abstrato, porquanto o ser (tò ón, substantivo abstrato derivado de eînai) que é percebido e pensado (do verbo noeîn) constitui-se em ontologia, "pois o mesmo é a pensar e portanto ser", sentença nuclear da doutrina de Parmênides ${ }^{25}$.

\section{3- $\quad$ O CAMINHO DA JUSTIÇA}

Da univocidade do Ser e da exclusão do Não-Ser, Parmênides irá enunciar os princípios lógico-ontológicos da identidade e da contradição, o que implica uma

\footnotetext{
${ }^{22}$.Tradução de José Cavalvante de Souza, Os pré-socráticos, da Coleção Os Pensadores, p.122. A problemática do Ser e do Não-Ser é intensamente discutida pelos comentadores, indicando-se entre os principais: Burnet (Op. cit., p.149-150); Brun (1991, p.61-64; Kirk., Raven, Schofield (Op.cit, p. 255-256); Marques (Op. cit p.55-67).

${ }^{23}$.Ver em especial o trabalho desenvolvido por Charles H. Kahn no que concerne ao uso veritativo do verbo ser em grego, em Sobre o verbo grego ser e o conceito de ser, passim.

${ }^{24}$.Op.cit, p.70.

${ }^{25}$.Este verso, traduzido como "pois pensar e ser é o mesmo", por Gerd Bornheim, em Os filósofos présocráticos. 7. ed. São Paulo: Cultrix, 1991, p.55, tem suscitado várias polêmicas entre os estudiosos do período pré-socrático. Kirk, Raven e Schofield (Op. cit., p.257) comentam que este fragmento foi acrescentado por Clemente e Plotino, tendo sido omitido no relato doxográfico de Simplício.
} 
descontinuidade com o pensamento anterior, dominado pela palavra ambígua e mágica de Alétheia, pura epifania, para se converter em discurso racional, regido pela "lógica da contradição" ${ }^{26}$, Alétheia dessacralizada. No Caminho da Verdade anunciado, Parmênides irá revestir Alétheia de atributos que convergem para a ideia de unidade do Ser, desviando-se da equivocidade de predicados múltiplos e contraditórios: o Ser é "ingênito", “imperecível”, “indivisível”, “uno”, “contínuo”, “imóvel”, “completo”. Deve-se enfatizar que o plano divino interfere no discurso argumentativo, pois Dike, Anánke (necessidade, destino) e Moîra (o destino de cada um ${ }^{27}$ compóem "a tríplice presença divina de deusas com poderes de ligação, ordenação, amarração e encaminhamento unificado." ${ }^{28}$ Com efeito, todo o férreo encadeamento lógico elaborado por Parmênides tem na "metáfora das correntes" 29 , que as divindades expressam, um suporte eficiente para apontar um novo caminho, um novo método de raciocínio, como pode-se constatar na exposição da deusa:

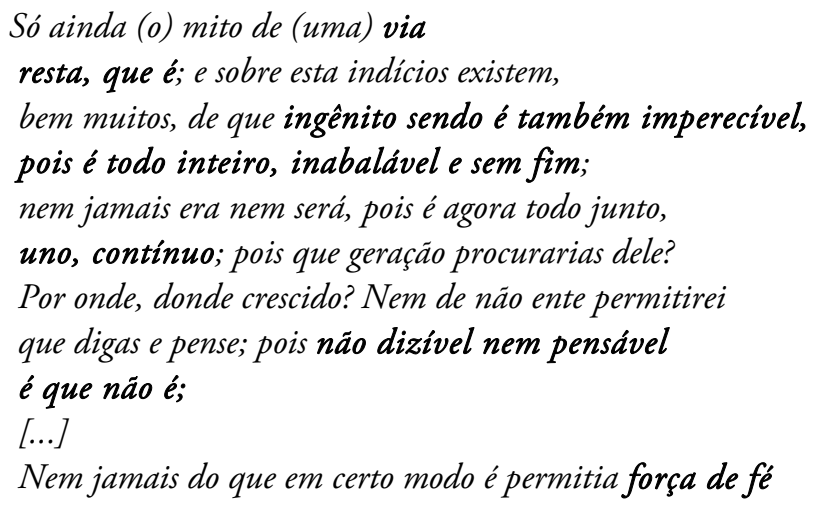

${ }^{26}$.DETIENNE, 1988, p.74.

${ }^{27}$.De acordo com as informaçóes contidas no Glossário de termos gregos, do livro Introduçáo à história da filosofia: dos pré-socráticos a Aristóteles, v.1, de Marilena Chauí, Anánke significa "a necessidade como constrangimento ou coerção; destino inevitável e inelutável determinado pelos deuses; [...]; lei na natureza. Inicialmente indica os laços de sangue que determinam o destino individual pelos laços do parentesco da família e da estirpe; a necessidade significa que não se pode negar a origem e o destino que ela impóe a alguém; juridicamente, que náo se pode negar a herança a alguém e alguém não pode recusar-se a receber a herança da família (estes sentidos são próprios de uma sociedade aristocrática e é desta necessidade-destino que falam as tragédias gregas). Necessidade é a ordem das coisas estabelecidas pela divindade como lei; lei da Natureza. Coisas e humanos são forçados ou constrangidos a ser como são e a agir como agem por força da necessidade (divina, natural). Opóe-se ao acaso. [...]", p. 494-495; Moîra quer dizer "o destino de cada um, a necessidade que rege o curso das coisas. É uma palavra da mesma família de méros, parte. [...] A moîra é a parte ou quinhão que cabe a cada um e, por extensão, o destino. [...]", p.506.

${ }^{28}$. MARQUES, O caminho poético de Parmênides, p.73.

${ }^{29}$.G.S. KIRK; J.E. RAVEN; M. SCHOFIELD, Os filósofos pré-socráticos: história crítica com selecção de textos, p.259. Cf. no mesmo sentido Marques (Op. cit., p.72-74). 


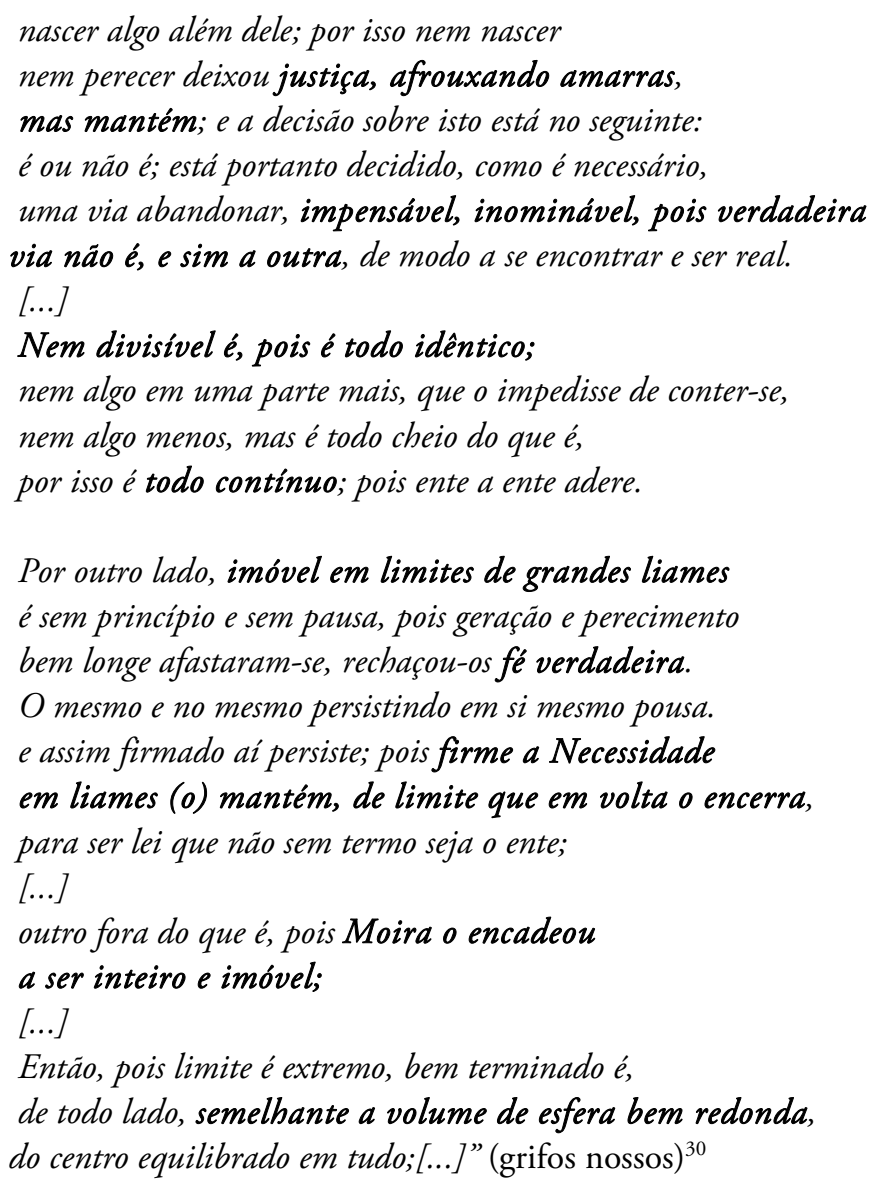

Dike, a "Justiça de muitas penas", é potência divina vinculada à Alétheia: é ela que guarda as chaves do caminho da verdade. Implacável, ela simboliza a ordenaçáo do mundo, a sentença que declara a medida justa. No poema parmenideano, articulada à revelação da verdade, ela assume também o papel corretivo da razão ao estabelecer com rigor os pressupostos lógicos do pensamento ${ }^{31}$. Da mais alta relevância é a invocação que a deusa faz da "lei divina e justiça", ou seja, de Thémis e Díke, intimamente associadas para conduzir o jovem à verdadeira consciência filosófica. Consoante aprecia Marcelo Pimenta Marques, "utilizando Thémis e Díke conjuntamente, Parmênides articula uma lei que ultrapassa o humano e uma norma que se inscreve nele. A partir dessa articulaçáo ele aponta para os

\footnotetext{
${ }^{30}$.Traduzido por José Cavalvante de Souza, em Os pré-socráticos, da Coleção Os Pensadores, p.123-124.

${ }^{31}$.Cf. Detienne (Op. cit., p.70).
} 
caminhos que se distinguem à medida que se aproximam ou se afastam da lei divina." 32

As concepçôes relativas à Thémis e à Díke, vale dizer, ao sentido de justiça divina e de prescrição imperativa, são referências importantes na elaboração de um discurso filosófico de validade universal, capaz de fixar com solidez os fundamentos essenciais que deverão nortear o homem na sua existência. O conceito consagrado de Thémis e Díke aflora com mais nitidez na medida em que se investiga a origem etimológica dessas palavras, conforme demonstra Émile Benveniste: Thémis provém do sânscrito rta correspondente ao vocábulo latino ars, que significa "ordem", e também de dhaman, em grego thémis, sentido de "lei", cuja raiz dhe quer dizer "estabelecer", "colocar", ou seja, Thémis passa a representar a lei posta que tem por base uma ordem divina ${ }^{33}$; Dike, por seu turno, deriva da raiz deik, resultando em grego deíknumi (mostrar) e em latim dico (dizer), donde o significado de mostrar verbalmente, com autoridade, uma prescrição normativa ${ }^{34}$. Em outras palavras, é Dike quem vai dizer a Justiça, com fundamento na lei divina, para mostrar ao homem que deseja saber o caminho da verdade.

Observa-se que, no discurso do Caminho da Verdade, Parmênides entrelaça uma linguagem de referências míticas com as novas exigências do pensamento na tentativa de dar credibilidade ao pólo subjetivo que se impóe como critério definitivo da verdade e da realidade. Trata-se da glorificação da "deusa da Razão" ${ }^{35}$, como afirma Cornford, a qual instaura um domínio absoluto sobre a questão do pensar e do ser, enlaçando-os firmemente num círculo fechado, deduzido formalmente mas petrificado nas muralhas da abstração. A lógica da identidade e da contradição formula um método more geometrico para perquirir a

\footnotetext{
${ }^{32}$.Op. cit, p.51.

${ }^{33}$.Cf. Le vocabulaire des institutions indo-européennes: Pouvoir, Droit, Religion, v.2, p.99-103; a raiz dhe, significando colocar, estabelecer, derivou em grego títhemi. O sentido de Thémis encontra--se no Dictionnaire Grec-Français, de A. Bailly, p.922.

${ }^{34}$.Cf. Benvnsite (Op. cit., p.107-109). Ver, igualmente, o significado de Dike no Dictionnaire GrecFrançais, de A. Bailly, p.511.

${ }^{35}$.CORNFORD, Principium sapientiæ: as origens do pensamento filosófico grego, p.194. Ver a respeito da razão, ordenadora dos critérios do conhecimento e do real, MONDOLFO, Rodolfo. O homem na cultura antiga: a compreensão do sujeito humano na cultura antiga, Trad. Luiz Aparecido Caruso. São Paulo: Mestre Jou, 1968, p. 102, em que afirma que "a razáo determina as condiçôes da conceptibilidade, e a conceptibilidade se erige em critério da realidade; as exigências interiores do sujeito pensante se convertem em árbitro da existência objetiva."
} 
verdade que dará base a uma predicação coesa, inteligível, racional. O círculo fecha-se no ser reflexivo, mundo inviolável e inabalável, construindo formas perfeitas de verdade, que, na visão nietzscheana, "só pode habitar nas generalidades mais pálidas e usadas, nos invólucros vazios das palavras mais indefinidas, como numa casa de teias de aranha: e o filósofo está agora sentado ao lado desta 'verdade', exangue como uma abstracção e completamente enredado em fórmulas." ${ }^{\text {36 }}$

O Caminho da Verdade tem sido considerado a via condutora da Metafísica e da Lógica ocidental, excluindo o não-ser de suas cogitaçôes. Martin Heidegger, todavia, na Introdução à metafísica, reivindica que o caminho do náo-ser deve ser pensado, porquanto constitui um aspecto importante da meditação ontológica. Heidegger insiste na mútua correspondência entre phýsis e lógos, como momentos pertencentes ao des-velamento do Ser, relação rompida pela tendência em priorizar a lógica na filosofia posterior. O fragmento acima transcrito, "pois o mesmo é a pensar e portanto ser", em que aparece o verbo noeîn, comumente traduzido por conhecer e pensar, possui também o significado de perceber ${ }^{37}$, ou seja, é a phýsis como vigor surgente que se mostra à percepção para que sua essencialização seja realizada.

Essa conexão resgatada pela interpretação heideggeriana implica o reconhecimento não do princípio da identidade, mas a "reciprocidade" 38 entre o pensar e o ser - Alétheia revelada nesse processo de manifestação de pertença recíproca. $\mathrm{Na}$ verdade, a relaçáo originária entre phýsis e lógos possibilita ultrapassar o plano gnosiológico e adentrar numa dimensão ontológica, que reúne, inobstante a opiniáo contrária da tradição filosófica, Heráclito e Parmênides, pois, segundo a indagação de Heidegger, “onde mais poderiam

\footnotetext{
${ }^{36}$.A filosofia na idade trágica dos gregos, p.67. Cf. Cornford (Op. cit., p.192), quanto ao método geométrico empregado por Parmênides; e Marques (Op. cit., p.74-76) com relaçáo à circularidade e ao sentido compacto do ser presente no pensamento parmenideano.

${ }^{37}$.O significado de noền, no Dictionnaire Grec-Français, de A. Bailly, p.1.330, aponta o sentido de "aperceber-se de", "colocar no espírito", "ter no espírito um pensamento certo, justo". Cf. Brun (Op. cit, p. 64-65); Heidegger (1987, p.137 e 161-164;) Marques (Op. cit., p.79-81).

${ }^{38}$.NUNES, Passagem para o poético: filosofia e poesia em Heidegger, 2. ed. Sáo Paulo: Ática, 1992. (Ensaios 122), p.216.
} 
estar êsses dois pensadores gregos, os instauradores da dimensão de todos os pensadores, senão no Ser do ente?"39

A unidade de phýsis e lógos, resultante da mostração do Ser e da reunião operada em função do légein, permite que o homem se instaure na dinâmica da essencialização e, consequentemente, no ato de pensar o seu destino e de decidir sobre o caminho que deverá trilhar: a via do acesso à plenitude do Ser e à verdade revelada ou a via da aparência, da dissimulação, da negação do Ser. Em Parmênides, a Alétheia ainda carrega vestígios da ambiguidade que havia caracterizado o discurso mítico na medida em que a linguagem do poema estabelece correlaçóes pertinentes entre o ser e o pensar, intrinsecamente relacionados para servir de fundamentação para uma análise abrangente da existência.

Nesse aspecto, é importante sublinhar que, após haver unificado o ser e o pensar, Parmênides reforça essa identidade onto-lógica, no início do Caminho da Verdade, onde utiliza légein ("dizer") e noeîn ("pensar") conjuntamente para exprimir o ser em contraste com o não-ser, impensável e indizível; esta é a via contraditória percorrida pelos mortais que não fazem uso das suas capacidades reflexivas. Considerado como uma crítica explícita à teoria dos contrários de Heráclito, a passagem seguinte demonstra, não obstante, a convergência entre os dois filósofos: ambos lançam acerbas admoestações contra os que não são capazes de estabelecer as articulaçóes entre o ser e o pensar para alcançar uma identidade reveladora, vale dizer, o lógos heraclitiano e o ser parmenídico compartilham do mesmo pensamento originário ${ }^{40}$ :
Necessário é o dizer e pensar que (o) ente é: pois é ser, e nada náo é; isto eu te mando considerar. Pois primeiro desta via de inquérito eu te afasto, mas depois daquela outra, em que mortais que nada sabem erram, duplas cabeças, pois o imediato em seus peitos dirige errante pensamento; e sáo levados

\footnotetext{
${ }^{39}$.Introdução à metafísica, p.160. Cf. a explicitação de Heidegger a respeito da conexão entre phýsis, lógos e noein, na obra citada, p.137-200; no mesmo sentido, Brun (Op. cit., p.64-65); Marques (Op. cit., p.78-81). ${ }^{40}$.Cf. Kirk, Raven e Schofield (Op. cit., p.257-258); Marques (Op. cit., p.80-81. Vale acentuar que Martin Heidegger (Op. cit,, p.150-151), ao resgatar o pensamento originário dos primeiros pensadores, procura aproximar Parmênides e Heráclito, afirmando que a oposição estabelecida entre os dois pré-socráticos, inclusive levantada por Nietzsche, fundamenta-se numa falsa interpretação do pensamento primordial grego, em que ser e pensar estáo reciprocamente imbricados.
} 
como surdos e cegos, perplexas, indecisas massas, para as quais ser e não ser é reputado o mesmo e não o mesmo, e de tudo é reversivel o caminho. (grifos nossos) ${ }^{41}$

O poema de Parmênides está estruturado em torno de três caminhos mutuamente exclusivos, diante dos quais o jovem deve instruir-se para chegar à deliberação correta, que conduz ao verdadeiro conhecimento. O Caminho da Opiniáo dos mortais não foi preservado na sua inteireza, porém constitui um relato ambíguo acerca da visão cosmológica predominante, baseada em crenças contraditórias, convencionais, destituídas de verdade objetiva. A dóxa, entretanto, deve ser posta em confrontação com a verdade anunciada por Parmênides, porquanto ele está situado na pólis e a sua palavra não é apenas revelação mística, mas sobretudo diálogo persuasivo estabelecido com os homens ${ }^{42}$.

Ao iniciar o caminho da opiniáo dos mortais, a deusa reveste-se de toda a ambiguidade da Alétheia herdada da tradição mítica, reminiscência das Musas na Teogonia de Hesíodo, sendo Pístis e Peithó substituídas por Pseudés (“desconfiança”, “mentira”) e Apáte ("engano"), dimensôes negativas constitutivas de Alétheia, servindo de recurso expressivo para contrapor a demonstração da verdade absoluta à exposição da opinião instável e cambiável dos mortais:

Neste ponto encerro fidedigna palavra e pensamento sobre a verdade; e opinióes mortais a partir daqui aprende, a ordem enganadora de minhas palavras ouvindo. Pois duas formas estatuiram que suas sentenças nomeassem, das quais uma não se deve — no que estão errantes -; em contrários separaram o compacto e sinais puseram à parte um do outro, de um lado, etéreo fogo de chama, suave e muito leve, em tudo o mesmo que ele próprio mas não o mesmo que o outro; e aquilo em si mesmo (puseram) em contrário, noite sem brilho, compacto denso e pesado. $A$ ordem do mundo, verossimil em todos os pontos, eu te revelo, para que nunca sentença de mortais te ultrapasse. (grifos nossos) $)^{43}$

\footnotetext{
${ }^{41}$.Versos traduzidos por José Cavalcante de Souza, Op. cit., p.122.

${ }^{42}$.Cf. Detienne (Op. cit., p.71-72); Kirk, Raven e Schofield (Op. cit., p.264-267); Marques (Op. cit., p.81).

${ }^{43}$.Tradução de José Cavalcante de Souza, Os pré-socráticos, da Coleção Os Pensadores, p.124.
} 
No Caminho da Opiniáo, Parmênides desenvolve a metáfora unificante do poema centrada na contraposição entre claro x escuro, Luz x Noite, compondo uma tessitura poética coerente, apropriada para exprimir a dualidade das posiçóes irredutíveis. No entanto, seguindo a leitura heideggeriana, Parmênides não estaria propondo uma visão dicotômica entre essência e aparência, entre mundo inteligível e mundo sensível; ao revés, estaria ainda submerso na ambiguidade da palavra Alétheia, desbravando o caminho do Ser através de um processo de re-velação, em que o manifesto e o oculto mesclam-se continuamente. Para Heidegger, dóxa, em sentido lato, "é a consideração em que alguém se encontra" ${ }^{44}$, portanto, liga-se aos múltiplos aspectos do parecer, que constituem as opiniōes no convívio dos entes. Ao invés de representar a antítese da senda iluminada da verdade, o mundo da aparência integra-se na caminhada do conhecimento, pois cabe ao homem sábio discernir cuidadosamente os aspectos enganadores dos verdadeiros. A dóxa, por conseguinte, deve ser pensada como elemento indecomponível do Ser e da Alétheia, como explica Heidegger:

Estamos aonde queríamos chegar. Posto que o Ser, physis, consiste no aparecer, no oferecer aspectos, encontra-se essencialmente e portanto necessária e constantemente na possibilidade de apresentar um aspecto que justamente encobre e oculta o que o ente é na verdade, isto é, na dimensáo do re-velado e des-coberto (Unverborgenheit). Essa vista, em que o ente vem a estar, é aparência no sentido de simples aparentar. Onde há re-velação, des-cobrimento (Unverborgenheit) do ente, há também a possibilidade da aparência (Schein). E onde o ente aparece e assim se mantém firme por muito tempo, a aparência pode desfazer-se e desmanchar-se. (grifado no original) ${ }^{45}$

Consoante apreciação de Marcelo Pimenta Marques, a metáfora do caminho, poeticamente trabalhada por Parmênides, não implica exclusão e separaçáo das vias enfocadas; ao contrário, o percurso do jovem rumo ao saber e à verdade pressupóe a passagem e o constante intercâmbio entre as regióes do ser, do não-ser e da aparência,

\footnotetext{
${ }^{44}$.Op. cit., p.130. Ver também Gomperz (1949, book II, chapter II, p.181), em que o autor explica o significado de dóxa como sendo opinião, mas igualmente percepção, ou seja, "a idéia, ou visão, ou opiniáo a coisa que aparece aos homens como verdadeira. [...]", no original: "the idea, or view, or opinion — the thing that appears to men to be true").

${ }^{45}$.Ibid, p.131. Cf. no mesmo sentido Marques (Op. cit., p.86).
} 
porquanto "o caminho dos homens que erram pelo mundo é integrado à esfera de validade do saber, pois errar é uma figura da própria verdade (Alétheia) do ser." ${ }^{46}$ Deve-se ressaltar o significativo uso do verbo "errar" na medida em que remete a uma das mais interessantes abordagens da filosofia heideggeriana, perfeitamente aplicada à construção metafórica do poema. De fato, a insistência do homem em permanecer no esquecimento de seu Ser é analisada por Heidegger como um dos aspectos da errância.

A errância constitui a variação simultânea entre o desvelamento e a dissimulação em que o homem, ao invés de afirmar sua essência, é absorvido pela cotidianidade massificadora, impotente para vislumbrar a plenitude da compreensão do Ser. Mais uma vez, o filósofo alemão surpreende com sua terminologia, pois errância tem o duplo significado de equivocidade como também de caminhada sem rumo, no sentido de que, segundo a interpretação de Emmanuel Carneiro Leão,

nesse esquecimento moderno, isto é, nas fases de progresso da técnica e da ciência, se derrama a escuridão da "Noite Histórica" na qual o homem, perdendo os fundamentos de sua humanidade, "erra", sem pátria, no turbilhão de uma objetividade sempre mais absorvente de subjetividade. A "época" da técnica e da ciência é o império do homem apátrida em sua essência. ${ }^{47}$

Parmênides coloca o homem perante três caminhos distintos, submetido a uma escolha para alcançar a via reveladora da verdade. Todo o discurso parmenideano gira em torno da metáfora do caminho, indicando as vertentes que irão consolidar-se no pensamento filosófico ocidental. Na verdade, a opção por uma via unilateral significa um caminhar estéril, culminando numa aporia ${ }^{48}$ no nível gnosiológico e metafísico. Parmênides

\footnotetext{
${ }^{46}$.Op. cit., p.87.

${ }^{47} .1967$, p.17. Sobre o tema da errância, ver em especial Heidegger (1996, p.166-168); Stein (1993, p. 191192).

${ }^{48}$.De acordo com o glossário de termos gregos, do livro Introduçáo à história da filosofia: dos présocráticos a Aristóteles, v. 1, de Marilena Chauí, p.495, aporía ( $\alpha ; \pi 0 p i \alpha)$ é "palavra composta do prefixo negativo $a$ - e pelo substantivo póros (passagem, via de comunicação, caminho, trajeto). [...] Aporía significa: incapacidade de encontrar caminho ou trajeto; falta de uma via ou um meio de passagem; impossibilidade de chegar a um lugar; por extensão: impossibilidade de deduzir, concluir, inferir. A aporía é uma dificuldade insolúvel."
} 
pensa os três caminhos, distingue-os e unifica-os numa articulação poderosa, seguindo a interpretação de Heidegger:

Um homem verdadeiramente sábio não é aquele que persegue cegamente uma verdade. É sòmente aquêle que conhece constantemente todos os três caminhos, o do Ser, o do não-ser e o da aparência. Um saber superior e todo saber é superioridade, só é concedido àquele que experimentou o ímpeto alado do caminho para o Ser. Que não estranhou o espanto do segundo caminho para o abismo do Nada. E que aceitou, como constante necessidade, o terceiro caminho, o da aparência. ${ }^{49}$

A palavra da deusa - Alétheia, Razão - é um convite ao homem racional para que ele, cruzando os caminhos, possa efetuar a ligaçáo correta, instauradora da Verdade e da Justiça. Heidegger analisa o poema de Parmênides à luz de um enfoque unificador, desviando o homem da errância e conduzindo-o à verdadeira sabedoria.

\section{CONSIDERAÇÓES FINAIS}

Investigaram-se subsídios para explicar as primeiras formalizações sobre a Justiça em Parmênides. Os pré-socráticos, em particular Anaximandro, Heráclito e Parmênides, são porta-vozes de um pensar fundacional no que concerne à definiçáa sobre o justo, o que os habilita a serem considerados os primeiros teóricos da Justiça. Na verdade, a contribuição dos pré-socráticos vem sendo reabilitada nos tempos modernos como forma de recuperar as preciosas liçōes que esse pensamento legou para o patrimônio filosófico dos homens.

Por conseguinte, retornar aos gregos e, principalmente, iniciar pelos pré-socráticos, constituiu uma etapa imprescindível para refazer um caminho que nos leva a uma melhor inteligibilidade sobre o conceito de Justiça. Esse trajeto teórico pressupóe uma análise significativa dos escritos sobre esses pensadores, e, particularmente, Parmênides assume uma posição destacada em virtude do papel fulcral que desempenha na transição entre o período pré-socrático e as grandes teorizaçóes sobre a Justiça elaboradas pelos sistemas platônico e aristotélico.

${ }^{49}$.Introdução à metafísica, p.139. 
Com efeito, Parmênides, calcado na estrutura do poema Sobre a natureza, estabelece uma visão antitética sobre o plano opinativo e o abstrato, inteligível; para esse nível o homem sábio dirige-se com o intuito de desenvolver suas capacidades cognitivas e poder deduzir conceitos verdadeiros, hauridos de um processo intelectivo guiado pela Razão. Itinerário ainda povoado por componentes mágicos, herança da tradição mítica anterior, porém antevisão de uma esfera dominada por ideias claras e justas, rigidamente desenhada para evitar as equivocidades e as contradiçóes.

Destaca-se a metáfora do Caminho, simbolizando a viagem ascensional rumo ao plano teórico sonhado. Idealismo à vista. É o embriáo do sujeito cognoscente que surge nesta estrada nebulosa, ávido por saber - hýbris (excesso; desmedida) do filó-sofo. E a Justiça o conduz neste desiderato: o acesso ao conhecimento verdadeiro (da Justiça?), ao fundamento último que baliza o nómos (território; norma), mobilizador do pensamento do filó-sofo do direito, e questão nuclear desde o período pré-socrático. 


\section{REFERÊNCIAS BIBLIOGRÁFICAS}

ARISTÓTELES. Metafísica. Trad. Leonel Vallandro. Porto Alegre: Globo, 1969. (Biblioteca dos Séculos).

BAILLY, A. Dictionnaire Grec-Français. Redigé avec le concours de E. Egger; édition revue par L. Séchan et P. Chantraine. Paris: Librairie Hachette, 1950.

BARNES, Jonathan. Filósofos pré-socráticos. 2. ed. Trad. Julio Fischer. São Paulo: Martins Fontes, 1997.

BENVENISTE, Émile. Le vocabulaire des institutuons indo-européennes: Pouvoir, Droit, Religion. Paris: Les Éditions de Minuit, 1969, v.2. (Le Sens Commun).

BORNHEIM, Gerd A. (org.). Os filósofos pré-socráticos. 7. ed. São Paulo: Cultrix, 1991.

BRUN, Jean. Os pré-socráticos. Trad. Armindo Rodrigues. Lisboa: Ediçóes 70, 1991. (Biblioteca Básica de Filosofia).

BURNET, John. O despertar da filosofia grega. Trad. Mauro Gama. São Paulo: Siciliano, 1994.

CHAUÍ, Marilena. Introdução à história da filosofia: dos pré-socráticos a Aristóteles. 2. ed. ver. e ampl. São Paulo: Brasiliense, 2002, v.1.

CORNFORD, Francis MacDonald. Principium sapientiæ: as origens do pensamento filosófico grego. 2. ed. Trad. Maria Manuela Rocheta dos Santos. Lisboa: Fundação Calouste Gulbenkian, 1981.

DETIENNE, Marcel. Os mestres da verdade na Grécia arcaica. Trad. Andréa Daher. Rio de Janeiro: Jorge Zahar, 1988.

GERNET, Louis. Anthropologie de la Grèce antique. Paris: Flammarion, 1968.

GOMPERZ, Theodor at al. Greek thinkers: a history of ancient philosophy. London: John Murray, 1949, $4 \mathrm{v}$.

GUTHRIE, W.K.C. Os filósofos gregos de Tales a Aristóteles. Trad. Maria José Vaz Pinto. Lisboa: Editorial Presença, 1987. 
HEIDEGGER, Martin. Introdução à metafísica. 3. ed. Tradução, apresentação e notas Emmanuel Carneiro Leão. Rio de Janeiro: Tempo Brasileiro, 1987. (Biblioteca Tempo Universitário, 1). . Sobre a essência da verdade. In: __. Conferências e escritos filosóficos. Tradução e notas Ernildo Stein. São Paulo: Nova Cultural, 1996. (Os Pensadores). . Sôbre o humanismo. Tradução, introdução e notas Emmanuel Carneiro Leão. Rio de Janeiro: Tempo Brasileiro, 1967. (Biblioteca Tempo Brasileiro- 5). HESÍODO. Teogonia: a origem dos deuses. 3. ed. rev. Tradução e estudo Jaa Torrano. São Paulo: Iluminuras, 1995. (Biblioteca Pólen).

HOUAISS, Antônio; VILLAR, Mauro de Salles; FRANCO, Francisco Manoel de Mello. Dicionário Houaiss da língua portuguesa. Rio de Janeiro: Objetiva, 2009.

JAEGER, Werner Wilhelm. Paidéia: a formação do homem grego. 2 ed. Trad. Artur M. Parreira; adaptação do texto para edição brasileira Mônica Stahel M. da Silva; revisão do texto grego Gilson César Cardoso de Souza. São Paulo - [Brasília]: Martins Fontes Editora Universidade de Brasília, 1989.

KAHN, Charles H. Sobre o verbo grego ser e o conceito de ser. Trad. Maura Iglésias et al. Rio de Janeiro: Núcleo de Estudos de Filosofia Antiga; Departamento de Filosofia PUC-Rio, [s.d.]. (Série Filosofia Antiga 1 - Cadernos de Tradução 1).

KIRK, G.S.; Os filósofos pré-socráticos: história crítica com selecção de textos.RAVEN, J.E.; SCHOFIELD, M. 4. ed. Trad. Carlos Alberto Louro Fonseca. Lisboa: Fundação Calouste Gulbenkian, 1994.

LAÊRTIOS, Diôgenes. Vidas e doutrinas dos filósofos ilustres. 2. ed. Tradução do grego, introdução e notas Mário da Gama Kury. Brasília: Editora Universidade de Brasília, 1977.

MARQUES, Marcelo Pimenta. O caminho poético de Parmênides. São Paulo: Loyola, 1990. (Coleção Filosofia - 13).

MONDOLFO, Rodolfo. O homem na cultura antiga: a compreensão do sujeito humano na cultura antiga. Trad. Luiz Aparecido Caruso. Sáo Paulo: Mestre Jou, 1968. 
MORA, José Ferrater. Dicionário de filosofia. Trad. Roberto Leal Ferreira; Álvaro

Cabral. 2. ed. São Paulo: Martins Fontes, 1996.

MORENTE, Manuel Garcia. Fundamentos de filosofia: liçôes preliminares. 8. ed. Trad. Guilhermo de la Cruz Coronado. São Paulo: Mestre Jou, 1980.

NIETZSCHE, Friedrich Wilhelm. A filosofia na idade trágica dos gregos. Trad. Maria Inês Madeira de Andrade. Rio de Janeiro - Lisboa: Elfos -Edições 70, 1995. (Biblioteca e Filosofia).

NUNES, Benedito. Passagem para o poético: filosofia e poesia em Heidegger. 2. ed. São Paulo: Ática, 1992. (Ensaios 122).

PARMÊNIDES DE ELÉIA. Fragmentos: Sobre a natureza. In: Os pré-socráticos: fragmentos, doxografia e comentários. Seleção de textos e supervisão Prof. José Cavalcante de Souza. Trad. José Cavalvante de Souza et al. Sáo Paulo: Nova Cultural, 1996. (Os Pensadores).

PESSANHA, José Américo Motta. Do mito à filosofia. In: Os pré-socráticos: fragmentos, doxografia e comentários. Trad. José Cavalcante de Souza et al. São Paulo: Nova Cultural, 1996. (Os Pensadores).

PLATÃO. Parmênides (Ou: Sobre as Idéias. Gênero lógico). In:__. Diálogos de Platão: Parmênides - Filebo. Trad. Carlos Alberto Nunes. Belém: Universidade Federal do Pará, p. 19-85, 1974, v.VIII. (Coleção Amazônica/ Série Farias Brito).

SNELL, Bruno. Las fuentes del pensamiento europeo: estudios sobre el descubrimiento de los valores espirituales de occidente en la antigua Grecia. Trad. Jose Vives. Madrid: Editorial Razón y Fe, 1965. (Colección "Formas del Espiritu”).

STEIN, Ernildo. Seminário sobre a verdade: liçóes preliminares sobre o parágrafo 44 de Sein und Zeit. Petrópolis: Vozes, 1993.

ZELLER, Eduard. Outlines of the history of Greek philosophy. 13. ed. Trad. L. R. Palmer; rev. Dr. Wilhelm Nestle. New York: Dover, 1980. 